\title{
Research on the Constructing the Holistic Thinking Mode and Teaching Effect of Pharmacology
}

\author{
Lu-Feng Cheng', Jin-Sen Kang ${ }^{1}$, Qi Xu ${ }^{2, *}$ \\ ${ }^{1}$ Department of Pharmacology, School of Pharmacy, Xinjiang Medical University, Urumqi, Xinjiang, PR CHINA. \\ ${ }^{2}$ School of Basic Medical Sciences, Xinjiang Medical University, Urumqi, Xinjiang, PR CHINA.
}

\begin{abstract}
Context: As a bridge course between basic medicine and clinical medicine, pharmacology is a compulsory course for students majoring in clinical medicine. Aim: The purpose this teaching is to establish a holistic thinking mode, build student-centered curriculum system by optimizing the teaching design based on the network platform. Design: Construct receptor-based teaching mode. They are based on the network platform, helping students establishing the holistic thinking of medicine. The study included undergraduate clinical medicine class from 2017 to 2019, which was randomly divided into an experimental group with holistic thinking mode instruction and a control group with conventional instruction. The teaching effect was reflected by comparing the test scores of two groups. Methods: By using PBL, CBS or classroom discussion methods to connect all lectures with fundamental questions related to knowledge points, help student establish the logical thinking of the holistic view of "Pharmacology". Student test scores was expressed in the form of $\bar{x} \pm S D$ ). One-way ANOVA was used for the comparison between the two groups and SPSS 17.0 statistical software was used for statistical analysis. Results: The results shows that the phased, mid-term and final examination of the experimental class are significantly higher than those of the controls in 2017 $(P<0.05)$. With the increased using holistic thinking teaching mode among students, the final examination scores have improved steadily $(P<0.05)$. Conclusion: The receptorbased teaching mode, which are helpful to construct the overall pharmacological thinking and improve the teaching effect.
\end{abstract}

Key words: Pharmacology, Holistic thinking, Receptor-based, Network platform, Teaching effect.

Key Messages: The holistic thinking teaching pattern, based on receptor level, connect every single organ's exciting effect into a regular pattern of the whole system, which help student to polish the integrative knowledge frame system of pharmacology. And it can also enhance the memories of knowledge, improve the final exam results.

\section{INTRODUCTION}

Pharmacology is an important part of the knowledge system of medical students, and it is a compulsory course for medical students majoring in clinical medicine. ${ }^{1,2}$ Modern medicine's understanding of the nature of human physiology and pathophysiology is actually confirmed and discovered through agonists and antagonists, while other developments also depend on pharmacology and its methods and theories, therefore, this course involves a large number of prerequisite courses and subsequent professional courses, which makes the overall knowledge framework more complex.,34 At present, the traditional or single teaching mode is difficult to adapt to the current pharmacology teaching process. The teaching effect is not ideal. Drugs are obviously classified at the organ level, but each type of drug can act on different organs. Pharmacology textbooks are designed according to the systematic classification of drug use. ${ }^{5}$ Students are required to first construct a holistic view of medicine combined with
Submission Date: 01-02-2021; Revision Date: 28-05-2021; Accepted Date: 29-09-2021.

DOI: 10.5530/ijper.55.4.194 Correspondence:

Prof. Qi Xu

School of Basic Medical Sciences, Xinjiang Medical University, Urumqi-830011, Xinjiang, PR, CHINA.

Phone no: +86-991-2110305 E-mail: 21030755@qq.com

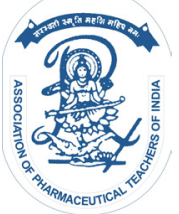

www.ijper.org 
basic courses such as physiology and pathophysiology, ${ }^{6}$ and then apply pharmacological knowledge to the knowledge system that has been constructed to gradually master emerging nervous system pharmacology, central nervous system pharmacology, cardiovascular system pharmacology, visceral system pharmacology, endocrine and so on. Constantly enrich the medical knowledge system. However, in practical teaching, students often complain that drug names and mechanisms of action are difficult to remember and understand and even students majoring in anesthesiology and stomatology think that pharmacology is not closely related to them, so they simply muddle through and cope with examinations. It directly affects the teaching effect and the study of follow-up related courses. Students complain about a curriculum system that is so useful for learning and memory. Of course, the complexity and diversity of drugs and organisms determine the complexity and diversity of pharmacological knowledge points, ${ }^{7}$ but the key problem is that we may ignore important logical clues in the knowledge system. ${ }^{8}$ In addition, there are many problems in some colleges and universities, such as outdated teaching materials, single traditional teaching forms, lack of innovation in teaching methods and so on, so that in most cases, students' interest in pharmacology is not high, passively accept knowledge, can't achieve good teaching results. ${ }^{9}$ At the same time, due to the lack of the establishment of medical holistic view and innovative thinking, it hinders the cultivation of medical innovative talents. To sum up, the purpose of pharmacology learning is to train students to understand the change of biology from phenomenon to essence and to establish logical thinking ability from essence to theory. Therefore, in teaching, we try to connect the scattered knowledge points through the core or several core ideas, summarize and refine their inherent laws, from point to line, from line to surface. For example, the receptor, as one of the important contents throughout the pharmacology course, ${ }^{10,11}$ takes it as a clue to connect the widespread distribution and diversity of cholinergic and adrenergic receptors in the chapter of nervous system pharmacology with the basic natural law of survival of the fittest in human evolution, starting from the common sense of life to the profound theoretical level, it can not only make students feel enlightened and improve their interest in learning. It can also make students experience the achievements and happiness in the process of logical thinking, ${ }^{12}$ and has achieved satisfactory results in constructing students' holistic view of medicine and stimulating students' enthusiasm for learning. The author has carried out practices in the past several classes of students and the results are quite satisfying and the students' response is quite satisfying.

\section{Construction of a holistic thinking mode based on receptor level pharmacology}

Based on the understanding of the physiological and path physical nature of the human body in modern medicine, it is actually confirmed and discovered through agonists and antagonists. Some chapters of pharmacology can combine physiology and related theory with practice through cell receptors, so that the role of drugs and their mechanisms from a single organ to the whole body. The whole teaching idea is: from the students' point of view, follow the law of education and teaching, start with macro phenomena and logical reasoning, analyze, introduce, summarize and then introduce the basic knowledge of physiology and biochemistry. Finally proved to be positive or negative (the use of agonists, blockers and other drugs). ${ }^{13}$ The process from macro to micro and from micro to backwardness is helpful for students to form a holistic view of medicine and establish an overall mode of thinking in pharmacology. In teaching, we first set up a team of interdisciplinary teachers, including physiology, pathophysiology, internal medicine and other professional teachers. Based on the receptor, through collective lesson preparation, demonstration teaching and other measures, the overall structure and teaching design of textbooks are re-planned and adjusted according to the different characteristics of students of different majors. The compilation of the teaching team starts from the receptor level and combines the theory and practice of physiology and other related disciplines, which is helpful to cultivate the integrated teaching plan of students' holistic view of medicine. Take the efferent nervous system pharmacology as an example, the traditional teaching method is mainly based on teaching, based on the distribution of receptors and the effect after excitation and introduce all kinds of receptors step by step. For example, there are two kinds of receptors on the effectors of adrenergic innervation: $\alpha$ and $\beta$ receptors, which are subdivided into $\alpha 1, \alpha 2$ receptors and $\beta 1, \beta 2$ and $\beta 3$ receptors. The idea of teaching is shown in Figure 1.

Because the traditional explanation mode ignores the internal relationship between knowledge and explains knowledge points in isolation, students may not be able to master knowledge points systematically and the proximity of unsystematic knowledge points and content can easily lead to students' difficulty in memory and confusion of knowledge points. and gradually lose interest in in-depth study of pharmacology. The efferent nervous system mainly takes acetylcholine receptor and 

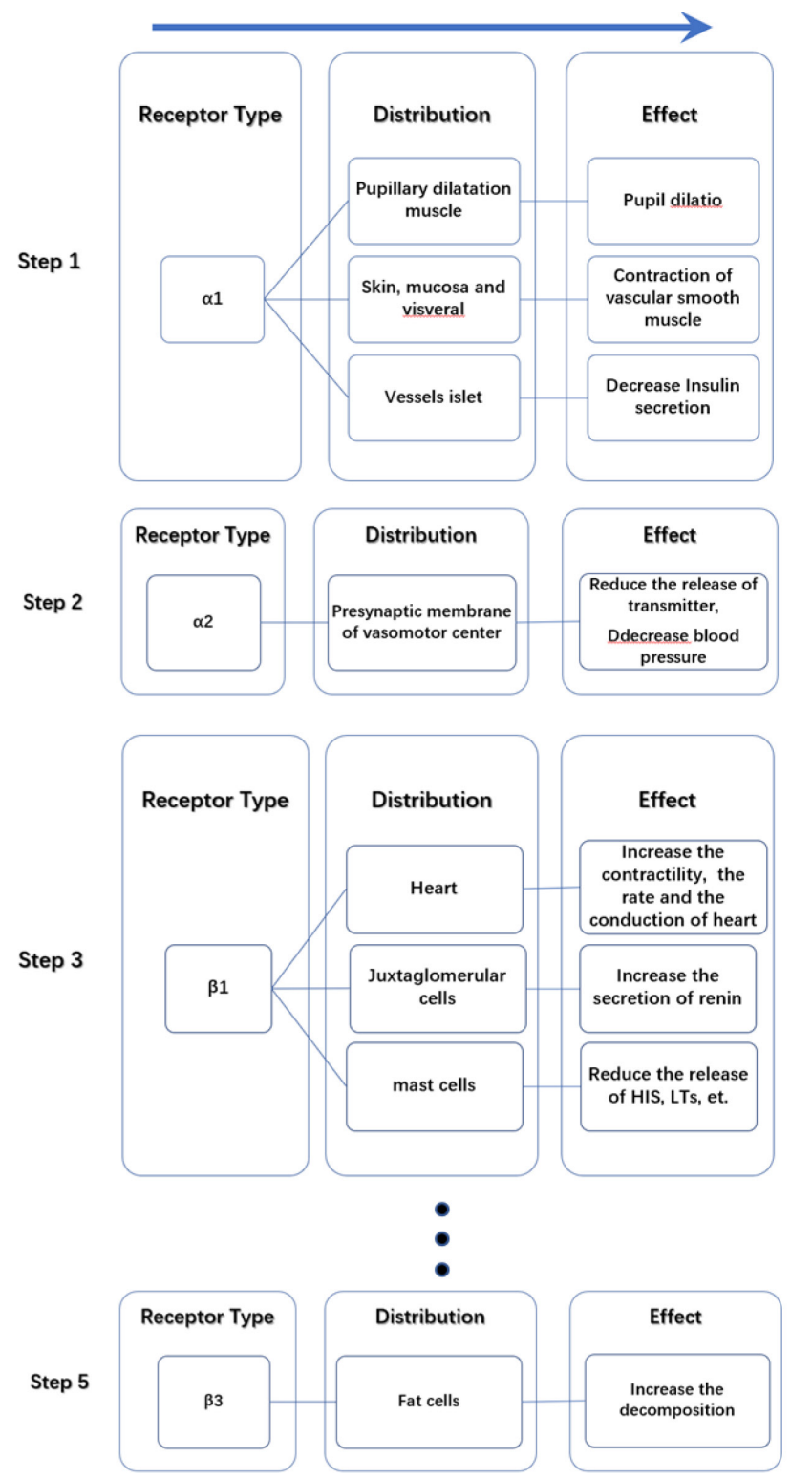

Figure 1: Traditional teaching content and process. The teaching begins with the type of receptor, then introduced the distribution and function according to different types separately. Steps $1,2,3 . .5$ are the introductions of $\alpha 1, \alpha 2, \beta 1$, $\beta 2$ and $\beta 3$ receptor, respectively.

adrenoceptor as the main line. According to the different receptors, all drugs can be divided into four categories, which are acetylcholine receptor agonists (direct agonists and indirect agonists) and antagonists. Adrenoceptor agonists and antagonists. According to the different receptor subtypes, the selective agonists and antagonists corresponding to the receptor subtypes can be divided into two groups. Therefore, although there are many drugs in this part, they are closely related to each other and it is easy to form an overall knowledge network, which is suitable for the construction of overall learning thinking. ${ }^{14}$ Through years of interdisciplinary teaching practice, the teaching team gradually combed out the main line of pharmacology teaching and constructed a receptor-based pharmacology teaching thinking mode Instructional design can use PBL, CBS or classroom discussion methods to connect all lectures with fundamental questions related to knowledge points. ${ }^{15,16}$ For example, in efferent neuropharmacology, according to the cause and performance of sympathetic excitation in the body, through the "jogging" experience that most students have had, the teacher separates all the excitatory effects of the body's receptors and explains the correlation between sympathetic stimulation and jogging. It enables students to experience the application of pharmacology in close combination with daily life, which greatly increases the enthusiasm and initiative of learning. The teaching ideas are shown in Figure 2.

The core question is-when exercising (running), which part of the body is most used? The answer is skeletal muscle. The energy sources for skeletal muscle movement are oxygen and glycogen. Oxygen is transported by the blood, so the skeletal muscle blood vessels must be expanded (the skeletal muscle vascular smooth muscle $\beta 2$ receptor is excited) to provide enough oxygen to the skeletal muscle. The heart functions as a pump to transport blood to the skeletal muscle blood vessels. Of course, the heart must accelerate its movement and its contractility, heart rate and conduction are accelerated (the heart's $\beta 1$ receptor is excited). Therefore, the work of the heart itself is enhanced and the amount of oxygen consumption increases and the coronary artery expansion (excitation of the $\beta 2$ receptor of the coronary artery) provides the heart itself with sufficient oxygen consumption and energy delivery. Besides oxygen, only when the bronchial smooth muscle expands (the bronchial smooth muscle $\beta 2$ receptor excites), can the outside fresh oxygen enter the body more to participate in sports consumption. When the skeletal muscle blood

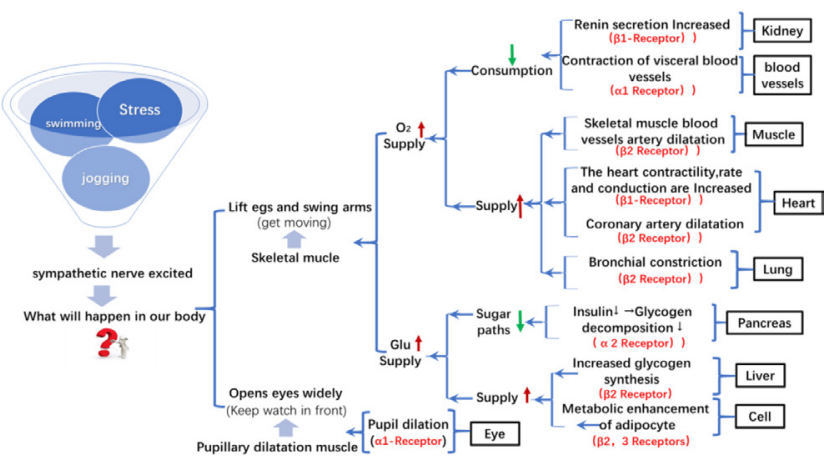

Figure 2: Sympathetic Excited Effects and Jogging. Through the analysis of body's functional state during jogging, the distribution and function of receptors in different tissues are derived, and on this basis, the physiology knowledge are integrated with pharmacology. 
vessels dilate and a large amount of blood flows to the skeletal muscle, the blood in the visceral blood vessels of the skin and mucosa must be reduced, so the vascular smooth muscle in these parts naturally contracts (the $\alpha 1$ receptor of the visceral smooth muscle in the skin and mucosa excites), plus Increased renin secretion (excitation of $\beta 1$ receptors in glomerular paracellular cells), so that increased synthesis of angiotensin II is also involved in the contraction of vascular smooth muscle of the skin, mucous membranes and internal organs. The second source of skeletal muscle energyglycogen, first of all, muscle glycogen, in order to provide sufficient energy consumption to skeletal muscle, of course, insulin release must be reduced at this time (the islet $\beta$ cell $\alpha 1$ receptor excites), otherwise how is glycogen metabolized by insulin to supply energy? In addition, the liver breaks down fat to make up for the rapid depletion of muscle glycogen, including the increased catabolism of fat cells (excitation of $\beta 2$ and $\beta 3$ receptors in fat cells). In addition, when running, the eyes should be widened (the $\alpha 1$ receptor of the mydriasis is excited) to see the road clearly to prevent wrestling. In short, most of the changes in organ levels after sympathetic nerve excitement are strung together with this line, which is where the author understands the "reason". From the perspective of the whole process, in the process of human evolution, motion is passive and stillness is active. Passiveness reflects the contradictory behaviors of human adapting to and reforming the environment, while the active state is due to human nature. At rest, it is the result of parasympathetic innervation, that is, the body is trimming the energy storage process, in order to survive and continue to compete with nature and adapt to the process. In this sense, when a person is resting, their heart activity weakens, their pupils shrink (drowse state), the gastrointestinal smooth muscles are excited and the secretion of the digestive glands increases to facilitate the digestion of food and reserve energy, which results in a relatively increased urination and defecation (sphincter relaxation, Detrusor contraction) and other behaviors are also connected in series. The above are the effects of $\mathrm{M}$ receptor excitation. This process of proving from the surface to the inside, from the macro to the micro and then from the micro to the macro proves to help strengthen the establishment of the logical thinking of the holistic view of "Pharmacology" in a short time and can make the memory of the learned knowledge solid, students will also benefit for life.

Pharmacology teaching starts with macroscopic phenomena and logical reasoning, which analyzes, introduces and summarizes, sets the drugs to be studied into the related logical framework and on the basis of reviewing the prerequisite courses such as physiology and pathophysiology, through the guidance and refinement of teachers, let student's master specific drugs in a close knowledge framework. And through students to cooperate with each other, ${ }^{17}$ actively complete thinking and discussion, constantly improve students' autonomous learning ability, ${ }^{18}$ promote the cultivation of students' holistic view of medicine and logical thinking, so as to improve examination scores and teaching results.

\section{Teaching design based on network platform}

The information-based teaching mode based on the network platform is a new generation of teaching mode facing the mobile Internet, which can be used in both computer and mobile phone. It has rich functions, simple and convenient operation and can integrate curriculum resources, pre-class preparation, classroom questioning, online practice, student attendance, discussion and other functions. The development of various network platforms, including mu class, rain class, micro class, QQ and so on, has laid a solid foundation for network information teaching. After determining the teaching ideas, a network teaching platform is constructed according to the actual situation of our school and a student-centered pharmacology curriculum system is established. Curriculum design is mainly divided into four parts: pre-evaluation, mid-evaluation, post-evaluation and post-evaluation. The design of each part focuses on student-centered learning process management and evaluation. Before class, teachers make instructional designs for different majors and classes and then upload the materials that need to be previewed, ${ }^{19}$ such as syllabus, multimedia courseware, micro-class videos, PBL cases ${ }^{20}$ exercises, etc. by Yu classroom or other network platforms, so that students can log in in the created class and then preview according to the content with the help of learning materials such as teaching plans and courseware provided by the platform. Enable students to have a preliminary understanding of the basic teaching process ${ }^{21}$ through the network platform. At the same time, students determine study groups before class and each group consults materials according to the information released by teachers on the network platform, carries out inter-group discussions and prepares a full set of plans for communication and use in class. In this process, teachers should pay attention to stimulating students' desire for knowledge and cultivate students' ability to think independently, analyze and solve problems and unite and cooperate. In classroom teaching, students are the main body and a variety of teaching methods and methods are used to improve students' interest and motivation in learning and 
promote students' exchange and discussion. According to the pre-class group for class report and discussion, students put forward their own questions, solve problems and constantly improve the knowledge system. Through the guidance of teachers, we should cultivate students' innovative and open thinking and promote students to integrate existing knowledge and new knowledge, make them master interdisciplinary knowledge comprehensively and systematically and actively analyze various phenomena of the body. Analyze the causes and infer the results. In the classroom, online exercises or tests can also be used to detect students' mastery of knowledge in real time. The teacher can release the class test through the rain classroom, which can be carried out in a designated, random and rush way and the system can automatically correct and immediately complete the test question analysis and score statistics and the teacher can grasp the students' mastery of knowledge in a timely manner. and to answer questions for students with learning problems. At the same time, the score can be incorporated into the usual score, so as to improve the students' concentration and efficiency in classroom learning. At the same time, we can understand the students' mastery of the experiment in real time through online exercises or Q \& A, so that teachers can adjust their teaching strategies in time. ${ }^{22}$ After class, online learning and real-time Q \& An are used to consolidate the learning effect. Finally, the formative evaluation and teaching reflection are carried out according to the contents of the above three parts and the results of the formative evaluation of the experimental class are included in the final comprehensive score. This also greatly improves the enthusiasm of students to use the network platform to learn and is conducive to the continuous improvement of teaching quality.

\section{Evaluation method based on holistic thinking teaching mode of receptor level pharmacology}

The clinical medicine parallel classes offering pharmacology courses in 2017 were randomly selected to construct the pharmacology teaching mode on the basis of the traditional teaching mode and the overall thinking based on the receptor level. The teaching of drugs in the efferent nervous system (the second phase) was assessed in stages and the results were statistically analyzed. Finally, for the mid-term and final exams, the horizontal comparison is based on the overall thinking mode at the receptor level to construct the teaching effect of pharmacology teaching and traditional teaching mode. At the same time, the final examination results of pharmacology clinical undergraduate major from 2016 to 2019 were selected to compare the teaching effect of this teaching mode longitudinally. ${ }^{23}$
Combined with the previous performance evaluation experience, ${ }^{24}$ in order to improve the comparability of the examination questions, the author makes an educational measurement analysis on the 2017 clinical undergraduate pharmacology stage examination questions, the mid-term examination questions and the 2016-2019 clinical medicine undergraduate pharmacology final examination questions. The results show that the above six questions have good reliability $(\mathrm{R}>0.9)$, moderate difficulty (0.25P) and good differentiation (D20.35). The test results are reliable and the difficulty is moderate, which can better measure the students' mastery of the knowledge they have learned. In the evaluation of learning effect, a total of 244 students from four classes majoring in clinical medicine in 2017 were divided into the control class and the experimental class, including 120 in the control class and 124 in the experimental class. According to the traditional teaching mode and the receptor-based teaching mode, which are helpful to construct the overall pharmacological thinking, the results of the periodic examination after the course show that the scores of the experimental class are significantly higher than those of the control class in the phased examination, mid-term examination and final examination $(P<0.05)$. The results are shown in Figure 3. After 2017, with the gradual progress of pharmacology teaching reform. The teaching of constructing the overall thinking of pharmacology has also been gradually piloted among the undergraduates majoring in clinical medicine in Grade 2018 and 2019. The final examination results of clinical medicine majors from

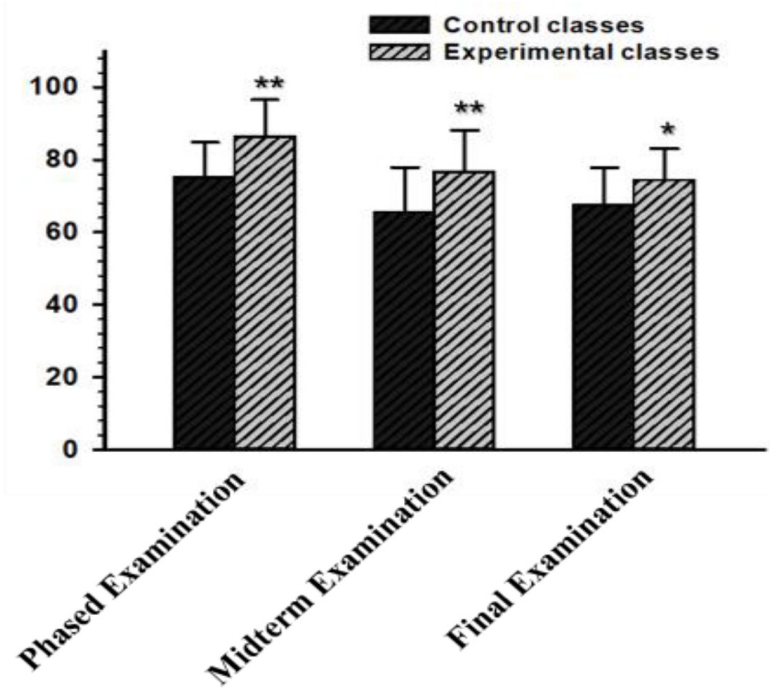

Figure 3: Effect of Holistic Teaching Model on Results of Pharmacology Phased Examination of undergraduates majoring in clinical medicine. Compared with control classes, ${ }^{* *} P<0.01,{ }^{*} P<0.05$. 


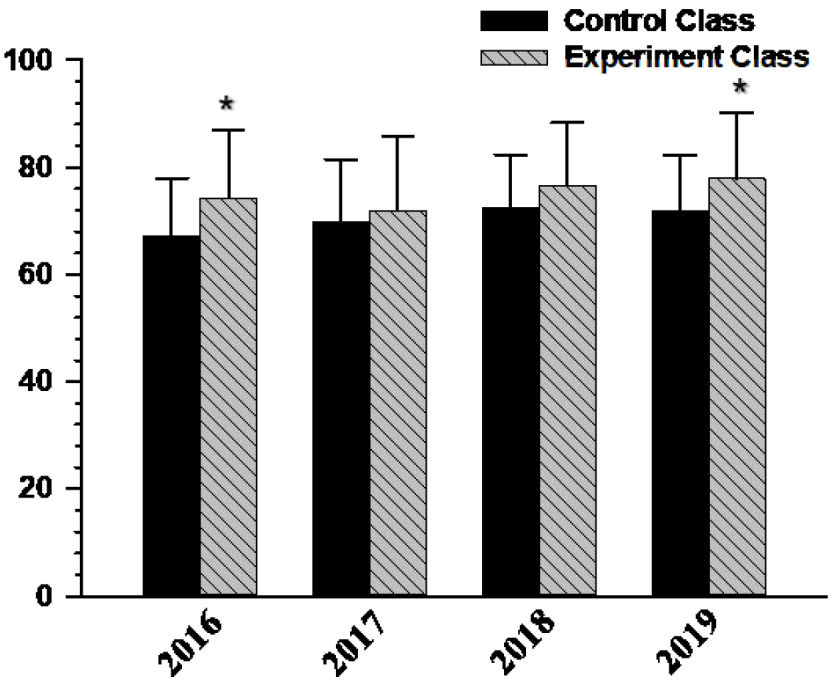

Figure 4: Effect of Teaching Model on Results of Pharmacology Final Examination of undergraduates majoring in clinical medicine from 2016-2019. Note: Compared with control classes ${ }^{*} P<0.05$

2016 to 2019 were compared longitudinally. The results show that with the increase of the proportion of pharmacology holistic thinking teaching mode among students $(50 \%$ of the total number of college students in 2019), students' final examination scores have improved steadily and the final examination scores of 2019 students have increased significantly compared with 2016. It is statistically significant $(P<0.05, P<0.01)$ and the results are shown in Figure 4.

\section{DISCUSSION}

The effectiveness of teaching and its evaluation consists of teaching process and final evaluation..$^{25}$ Based on receptor level to structure pharmacology integratedthinking teaching pattern. Starting with macroscopical phenomenon, cut into receptor level, integrate the theory and practice of physiology and functionality. Connect every single organ's exciting effect into regular pattern of the whole system, which helps to polish the integrative knowledge frame system of the pharmacology teaching that is suited. This kind of process from outward appearance to inner essence, from macrography to microcosm, then them prove repeatedly, which helps to strengthen the integrative logical thinking's establishment of pharmacology in a short time. And it can also enhance the memories of knowledge that will benefit students through all their lives. To improve the evaluating comparability between the same teaching content and different teaching pattern in this teaching pattern experimental design progress, the author used horizontal and vertical comparing patterns to compare the teaching pattern's effect of students' score. The horizontal comparison chose two classes of grade 2014 majoring in clinical medicine, which don't have much difference in the other courses' tests. The results of periodical test, mid-term examination and final examination show us : the mode of education that bases on receptor level to build the systematic thinking of pharmacology, start with macroscopical phenomenon and then cut to the logical reasoning, analyze concluding and summarize and lead in the basic knowledge of physiology and biochemistry, finally attest it is right or its contrary is wrong (by using medicines such as agonist, blocker etc.), link the effect of single excited organ in series as integrated systematic law, which helps students in building systematic thinking of pharmacology and improving students' performance obviously. The result of vertical comparison shows us: from 2017 to 2019 the undergraduate of Clinical Medicine Science that adopt the way based on receptor level to build the systematic thinking of pharmacology in different degrees, whose final examination can show: as the augment of this mode of education, the students' final exam results were improved steadily, this situation can be explained as this mode of education has obvious advantages in the teaching of pharmacology.

Study of practically teaching has been conducted for many years, ${ }^{26}$ which creates knowledge system of pharmacology based on receptor level and it makes use of transverse contrast applied when talking about classes in same level and semester while vertical contrast going on under professional identically classes in diverse years. Educational measurelogy will test and analyze its teaching effectiveness in which appears to be an apparent improvement in instructing pharmacology and greatly promote students interests in exploration of pharmacology. More and more the author feels the passion when teaching pharmacology to Figure out the nature of life. From experience of many years of scientific study, it normally occurs to me a question that you'll explore out of control once you are approaching the truth because curiosity is human nature. What is interest? That is! And that produces endless energy and set you free without limitation and hesitation. Thus, it's hard to stand that pharmacology unpopular among students. That's what the author reflects from teaching and initiative action of exploring the true essence of life during teaching. People, during the normal living process, should change their passive learning skills to active learning skills, maybe this is another active nature of human-beings: desire, people want to live longer and enjoy more happiness. This type of passive-to-active philosophical action is the primary condition of medical development, too. Isn't it? Actually, 
knowledge about philosophic thinking is another direction of teaching reform.

\section{ACKNOWLEDGEMENT}

We would like to thank colleagues in National first-class undergraduate specialty construction site of Pharmacy for their comments and suggestions on this project.

\section{CONFLICT OF INTEREST}

The authors declare no Conflict of interest.

\section{ABBREVIATIONS}

PBL: Problem-Based Learning; CBS: Case-Based Study; Q\&A: Question and Answer.

\section{REFERENCES}

1. Currie GM. Pharmacology, Part 1: Introduction to pharmacology and pharmacodynamics. J Nucl Med Technol. 2018;46(2):81-6. doi: 10.2967/ jnmt.117.199588, PMID 29599397.

2. Engels F. Pharmacology education: reflections and challenges. Eur J Pharmacol. 2018;833:392-5. doi: 10.1016/j.ejphar.2018.06.032, PMID 29935169.

3. Haranath PS. Medical curriculum and pharmacology: an appraisal. Indian J Pharmacol. 2016;48(Suppl 1):S10-3. doi: 10.4103/0253-7613.193328, PMID 28031600.

4. Kim DH, Lee JH, Kim SA. The pharmacology course for preclinical students using team-based learning. Korean J Med Educ. 2020;32(1):35-46. doi: 10.3946/kjme.2020.151, PMID 32130849.

5. El Hassouni B, Mantini G, Li Petri G, Capula M, Boyd L, Weinstein HNW, Vallés-Marti A, Kouwenhoven MCM, Giovannetti E, Westerman BA, Peters GJ, EORTC PAMM Group. To combine or not combine: drug interactions and tools for their analysis. Reflections from the EORTC-PAMM Course on Preclinical and Early-Phase Clinical Pharmacology. Anticancer Res. 2019;39(7):3303-9- doi: 10.21873/anticanres.13472, doi: 10.21873/ anticanres.13472, PMID 31262850

6. Steffen J, Lenski M, Herrmann FE, Mückter H, Dimitriadis K, Fischer MR. Improving the Pharmacology Curriculum at a German Medical School: A structured plan based on a student-guided large-scale study. J Clin Pharmacol. 2019;59(8):1151-57. doi: 10.1002/jcph.1410. PMID 30875103.

7. Alexander SPH, Christopoulos A, Davenport AP, Kelly E, Mathie A, Peters JA, Veale EL, Armstrong JF, Faccenda E, Harding SD, Pawson AJ, Sharman JL, Southan C, Davies JA, CGTP Collaborators. The concise guide to pharmacology 2019/20: G protein-coupled receptors. Br J Pharmacol. 2019;176;Suppl 1:S21-S141. doi: 10.1111/bph.14748, PMID 31710717.

8. Gill M, Andersen E, Hilsmann N. Best practices for teaching pharmacology to undergraduate nursing students: A systematic review of the literature. Nurse Educ Today. 2019;74:15-24. doi: 10.1016/j.nedt.2018.11.017, PMID 30554030.

9. Gulmez SE, Aydin V, Akici A. Footprints of Clinical Pharmacology in turkey: past, present and future. Clin Ther. 2020;42(2):351-62. doi: 10.1016/j. clinthera.2019.12.014, PMID 31955969.

10. Ferraiolo M, Beckers $\mathrm{P}$, Marquet N, Roumain M, Ruiz L, Dupuis N, et al. $\beta$-arrestin2 recruitment at the $\beta 2$ adrenergic receptor: $A$ luciferase complementation assay adapted for undergraduate training in pharmacology.
Pharmacol Res Perspect. 2021:9:e00706.doi: 10.1002/prp2.706. PMID: 33508174.

11. Borea PA, Gessi S, Merighi S, Vincenzi F, Varani K. Pharmacology of adenosine receptors: the state of the art. Physiol Rev. 2018;98(3):1591-625. doi: 10.1152/physrev.00049.2017, PMID 29848236.

12. Charfi R, Ben Hamida E, Klouz A, Trabelsi S, Loueslati MH. Progress and assessment of a contextualized teaching session of pharmacology. Tunis Med. 2018;96(1):6-11. PMID 30324985.

13. Rapoport B, Smit T. Clinical pharmacology of neurokinin-1 receptor antagonists for the treatment of nausea and vomiting associated with chemotherapy. Expert Opin Drug Saf. 2017;16(6):697-710. doi: 10.1080/14740338.2017.1325868, PMID 28460548.

14. Lanz A, Davis RG. Pharmacology Goes Concept-Based: Course Design, Implementation, and Evaluation. Nurs Educ Perspect. 2017;38(5):279-80. doi: 10.1097/01.NEP.0000000000000188, PMID 28787366.

15. Kaur G, Rehncy J, Kahal KS, Singh J, Sharma V, Matreja PS, Grewal H. Case-based learning as an effective tool in teaching pharmacology to undergraduate medical students in a large group setting. J Med Educ Curric Dev. 2020;7:2382120520920640. doi: 10.1177/2382120520920640, PMID 32435693.

16. Hasamnis AA, Arya A, Patil SS. Case-based learning: our experience in Clinical Pharmacology teaching. J Pharm Bioallied Sci. 2019;11(2):187-9. doi: 10.4103/jpbs.JPBS_135_18, PMID 31148897.

17. Hanson J, Andersen P, Dunn PK. The effects of a virtual learning environment compared with an individual handheld device on pharmacology knowledge acquisition, satisfaction and comfort ratings. Nurse Educ Today. 2020;92:104518. doi: 10.1016/j.nedt.2020.104518, PMID 32629336.

18. Patrick S, Vishwakarma K, Giri VP, Datta D, Kumawat P, Singh P, Matreja PS. The usefulness of crossword puzzle as a self-learning tool in pharmacology. $J$ Adv Med Educ Prof. 2018;6(4):181-5. PMID 30349830.

19. Ahsan M, Mallick AK. Use of prelecture assignment to enhance learning in pharmacology lectures for the 2nd year medical students. Indian J Pharmacol. 2016;48(Suppl 1):S65-8. doi: 10.4103/0253-7613.193326, PMID 28031612.

20. Brinkman DJ, Monteiro T, Monteiro EC, Richir MC, van Agtmael MA, Tichelaar J. Switching from a traditional undergraduate programme in (clinical) pharmacology and therapeutics to a problem-based learning programme. Eur J Clin Pharmacol. 2021;77(3):421-9. doi: 10.1007/s00228-020-03027-3 [Epub ahead of print]. PMID 33098019.

21. Carstensen SS, Kjaer C, Möller S, Bloksgaard M. Implementing collaborative, active learning using peer instructions in pharmacology teaching increases students' learning and thereby exam performance. Eur J Pharmacol. 2020;867:172792. doi: 10.1016/j.ejphar.2019.172792, PMID 31733212.

22. Badyal DK, Bala S, Singh T, Gulrez G. Impact of immediate feedback on the learning of medical students in pharmacology. J Adv Med Educ Prof. 2019;7(1):1-6. doi: 10.30476/JAMP.2019.41036, PMID 30697542.

23. Kühbeck F, Berberat PO, Engelhardt S, Sarikas A. Correlation of online assessment parameters with summative exam performance in undergraduate medical education of pharmacology: a prospective cohort study. BMC Med Educ. 2019;19(1):412. doi: 10.1186/s12909-019-1814-5, PMID 31703687.

24. Sumanasekera W, Turner C, Ly K, Hoang P, Jent T, Sumanasekera T. Evaluation of multiple active learning strategies in a pharmacology course. Curr Pharm Teach Learn. 2020;12(1):88-94. doi: 10.1016/j.cptl.2019.10.016, PMID 31843171.

25. Yadav PP, Chaudhary M, Patel J, Shah A, Kantharia ND. Effectiveness of integrated teaching module in pharmacology among medical undergraduates. Int J Appl Basic Med Res. 2016;6(3):215-9. doi: 10.4103/2229-516X.186962, PMID 27563591.

26. Arcoraci V, Squadrito F, Altavilla D, Bitto A, Minutoli L, Penna O, Amato A, Bruno R, Tripodi VF, Alibrandi A, Ingrassia PL, Santalucia P, Fodale V. Medical simulation in pharmacology learning and retention: A comparison study with traditional teaching in undergraduate medical students. Pharmacol Res Perspect. 2019;7(1):e00449. doi: 10.1002/prp2.449, PMID 30651989. 
PICTORIAL ABSTRACT

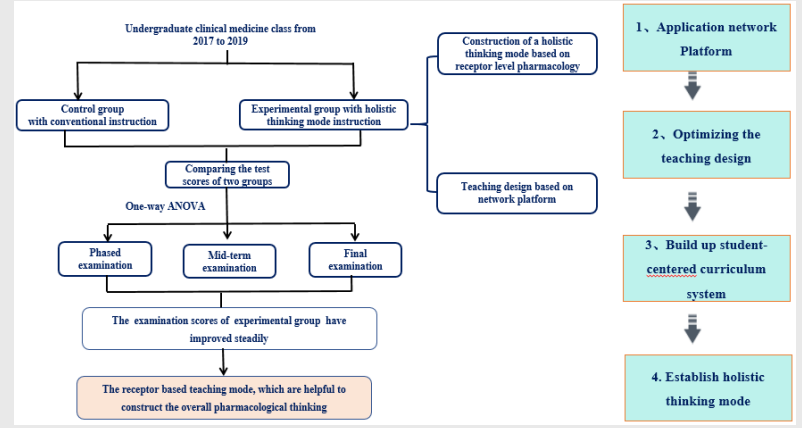

\section{SUMMARY}

In this teaching research, from the level of receptor, integration of physiology, function and so on related theory and practice, series single organ after the excitement effect into the law of the system as a whole, emphasize students "point - line - face" of the construction of the overall thinking, set to study drugs to the associated logic framework, through the teachers' leading and refining, lets the student in closely the knowledge framework of specific drugs, to strengthen the cultivation of the students' overall thinking at the same time.

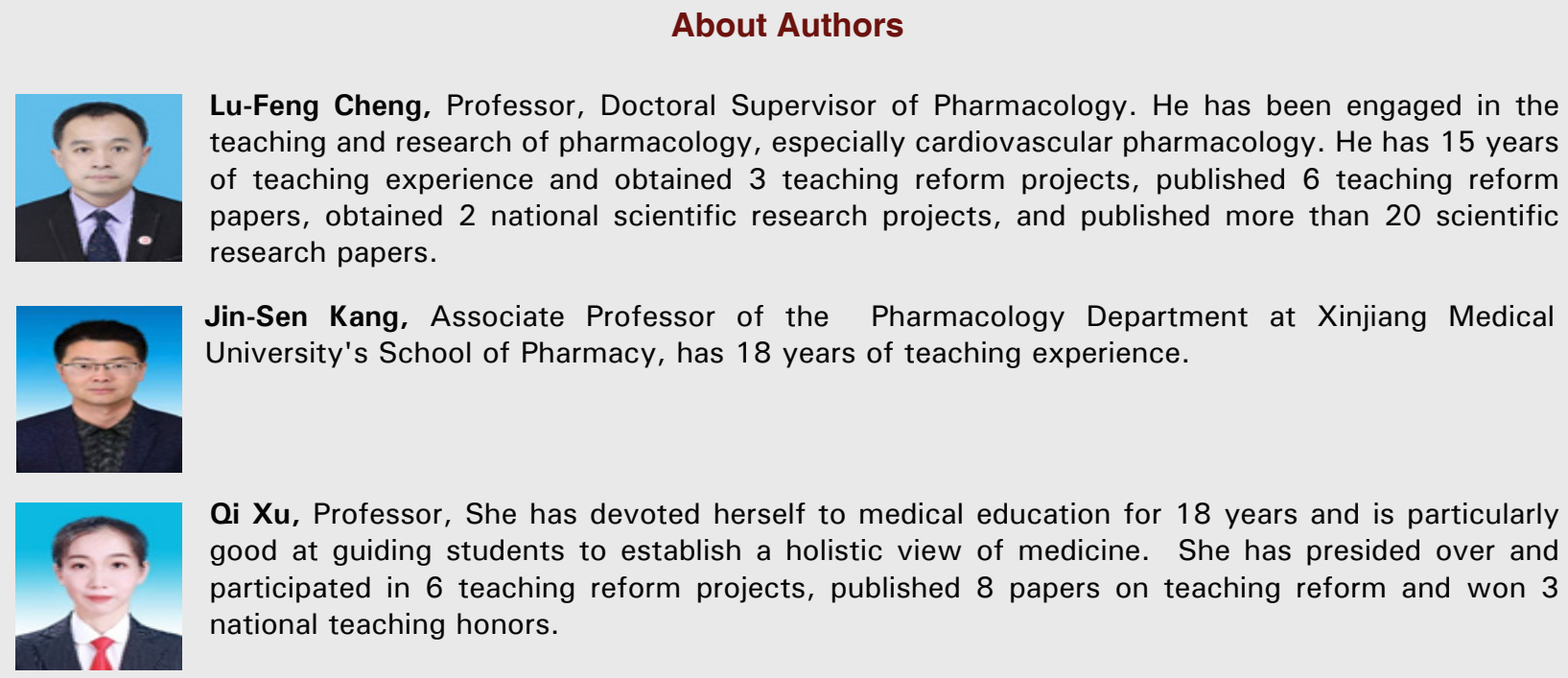

Cite this article: Cheng LF, Kang JS, Xu Q. Research on the Constructing the Holistic Thinking Mode and Teaching Effect of Pharmacology. Indian J of Pharmaceutical Education and Research. 2021;55(4):939-46. 